\title{
Globalization and Income Inequality in G7: A Bootstrap Panel Granger Causality Analysis
}

\author{
Feyza Balan ${ }^{1}$, Mustafa Torun ${ }^{1} \&$ Cuneyt Kilic ${ }^{1}$ \\ ${ }^{1}$ Biga Faculty of Economics and Administrative Sciences, Canakkale Onsekiz Mart University, Canakkale, \\ Turkey \\ Correspondence: Feyza Balan, Biga Faculty of Economics and Administrative Sciences, Canakkale Onsekiz \\ Mart University, Canakkale, 17200, Turkey. Tel: 90-286-335-8738. E-mail: feyzarica@ gmail.com
}

Received: July 1, 2015

Accepted: August 22, 2015

Online Published: September 25, 2015

doi:10.5539/ijef.v7n10p192

URL: http://dx.doi.org/10.5539/ijef.v7n10p192

\begin{abstract}
In this research, the relationship between income inequality and the KOF index of globalization is determined using panel data covering G7 countries 1970-2010. This study applying Kónya (2006)'s bootstrap panel Granger causality test, which takes into account cross-sectional dependence and slope heterogeneity simultaneously, analyzes the impact of globalization on income inequality in terms of economic, social, political and overall dimensions among examined countries. Empirical results indicate one-way causality from economic globalization to income inequality in Canada and France, two-way causality between economic globalization to income inequality in only the UK; one-way causality from social globalization to income inequality in France and the UK; one-way causality from political globalization to income inequality in only France. When analyzing the causality between the aggregate globalization and income inequality, it is observed that overall globalization positively causes income inequality in Canada and the UK and negatively in France, while in the case of Germany, Italy, Japan and the USA there is no empirical evidence of causality between globalization indices and income inequality in either direction.
\end{abstract}

Keywords: globalization, income inequality, bootstrap, panel causality, cross-sectional dependence, slope heterogeneity

\section{Introduction}

In recent years, globalization, mostly defined as the free movements of goods and services, capital, people, information, technology and management knowhow across borders, and its economic, social and political dimension have been intensely studied by economists and policymakers. Like globalization, income inequality also attracts great attention due to increasing skewness of income distribution across most countries over the years.

From the review of the literature on the relationship between income inequality and globalization, it is clear that the impacts of globalization and its modes on income distribution differ across countries in accordance with the macroeconomic and labour market policies. However, inequality due to globalization today is often thought to have two versions: "the less-worse" and "the worse" versions. According to Maskin (2014) in the "less-worse" version, inequality seems to be a necessary side-effect of increased economic growth within a country. Through globalization, the wages of a segment of the work force increase, but the same increase doesn't happen for other segments, so the gap increases. In the "worse" version, the wages of low-skilled and low-wage workers drop as a result of less demand for their skills, while the wages of higher skilled workers increase (Maskin, 2014).

Using the bootstrap panel causality approach, developed by Kónya (2006), the objective of this study is to empirically investigate causality between income inequality, measured with the Gini coefficient and the KOF globalization index, developed and first used by Dreher (2006), for G7 countries over the period of 1970-2010. Thus, this paper differentiates from the existing literature by examining the link between income inequality and globalization in two aspects. First, it is focused on the effects of globalization on income inequality in terms of both individual economic, social and political dimensions of globalization and the aggregate globalization. Second, it applies the bootstrap panel Granger causality approach, developed by Kónya (2006), which considers cross-sectional dependence and country-specific heterogeneity simultaneously among G7 countries over a period of 40 years. 
The remainder of this paper is organized as follows. Section 2 establishes the links between the various channels of globalization and inequality based on the existing literature. Section 3 presents the data set, the methodology and the empirical results. Finally, Section 4 reviews our conclusions.

\section{Globalization and Its Impacts}

Economic dimension of globalization is defined as the integration of economic activities, primarily via markets. In general economic globalization covers the four main globalization factors. These are:

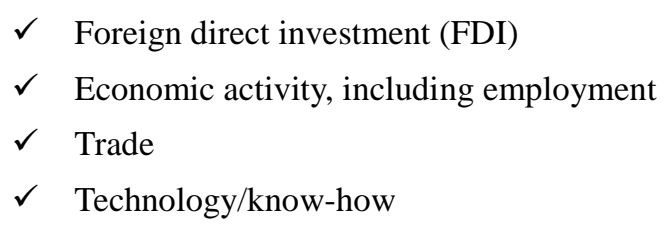

During the early 1980s, FDI accelerated, both absolutely and as a percentage of GDP. Since 1980, the political environment worldwide has played an important role in the growth of FDI.

According to ILO (2004), another most important element of globalization over the past three decades has been the rapid integration of financial markets. Financial liberalization constituted the policy environment for expanded capital mobility. But the increase in capital flows was greatly boosted by the revolution in Information and Communications Technology.

The industrialized countries were the roots of the technological revolution that facilitated globalization but that revolution has also had ripple effects on the rest of the global economy. At one level, the new technology changed international comparative advantage by making knowledge an important factor of production. The knowledge-intensive and high-tech industries are the fastest growing sectors in the global economy and successful economic development will eventually require that countries become able to enter and compete in these sectors, which implies that they will have to emphasize investments in education, training and the diffusion of knowledge (ILO, 2004).

In addition, the institutional context for international economic relations also began to change, thanks to globalization. A new round of multilateral trade negotiations launched in 1986 set the stage for the transformation of GATT into the WTO in 1995. A key change was the broadening of the agenda of trade negotiations well beyond the GATT remit of reducing tariffs and other direct barriers to trade (ILO, 2004).

Globalization requires changes in economic structure, relative prices, and consumption possibilities and patterns, which in turn affects peoples' jobs, livelihoods and incomes. The distribution of economic benefits and social costs of globalization are not fair among social groups. Thus, in many countries some groups of workers have been adversely affected by trade liberalization and the relocation of production to lower-wage economies. In some countries, globalization has resulted in serious gender imbalances. The extent of this imbalance depends largely on the level of gender equality prevailing in the norms, institutions and policies of a country at the time when integration into the global economy takes place (ILO, 2004).

In order to assess the social impact of globalization it is essential to go beyond economic performance and examine what happened to employment, income inequality and poverty over the past three decades of globalization. The mixed picture that emerges on economic performance and on changes in employment, inequality and poverty makes it extremely difficult to generalize on what the impact of globalization has been. In part this is because globalization is a complex phenomenon (ILO, 2004).

According to UNDP (2013), the distribution of personal or household income depends on three factors: the distribution of labour endowments, the distribution of capital endowments, and the way in which aggregate output is shared between the labour and capital. In addition to these factors, globalization and its modes, such as trade globalization and financial globalization also have been seen as exogenous drivers of income inequality (UNDP, 2013).

As can be understood that economic globalization has, in turn, cultural, social, and political consequences. In this study, we focused on the relationship between income inequality and globalization.

\section{Literature Review}

There has been a comprehensive body of literature on globalization and its impacts on inequality among nations. For example, using trade openness index as an indicator of globalization, Milanovic's (2002) empirical results based on cross-country econometric analysis suggest that openness worsens individual countries' income distribution before improving it, and that the effect of openness on income distribution depends on the country's 
initial income level. Thus, Milanovic (2002) suggests that an inverted U-shaped Kuznets curve is valid for the openness-income distribution relationship, which means that at low income levels, openness worsens income distribution, but beyond a certain level, higher income promotes equality. Similarly, studying China over the period 1952 to 2009, Jalil (2012) suggest that there is a non-linear relationship between trade openness and inequality and concluded that inequality is positively associated with trade openness, but it falls after a certain threshold value.

Heshmati (2004) investigated the effects of globalization on income inequality for 62 countries for the period of 1995-2001. Used two globalization measurements: the composite globalization index of Kearney and a globalization index based on principal component analysis (Heshmati, 2004). Using Gini coefficient as a measurement of income inequality, Heshmati (2004) showed that globalization index explains only 7-11 percent of the variations in income inequality among the countries, examined. Moreover, when decomposing the Kearney's globalization index into four sub-components, Hesmati's results showed that personal contacts and technology transfers reduce inequality, while economic integration increases inequality. Political engagement, the fourth sub-component of the globalization index, is found to have no significant effects on income inequality in his study.

According to Dollar and Kraay (2004), a key issue today is the effect of globalization on income inequality and poverty. They find evidence that the increase in growth rates leads on average to proportionate increases in incomes of poor countries and that globalization triggers to faster growth and poverty reduction in poor countries. Dollar and Kraay (2002) also point out that growth is good for the poor, and conclude that trade leads to higher growth, which in turn reduces poverty, so globalization is also good for the poor. From this point of view, Agénor (2004) examined the extent to which globalization affects poverty using a cross-country regression framework for a group of developing countries. Using both individual indicators of trade and financial openness and a globalization index based on principal components analysis, Agénor (2004) showed that there is a non-monotonic Laffer type relationship between the variables, namely globalization appears to hurt the poor at low levels, but beyond a threshold, it appears to reduce poverty.

Kalwij and Verschoor (2005) investigated the impact of globalization both on global and local inequality for six major developing regions over the period 1980-1998. They stated that the income and inequality elasticities of poverty change overtime in most regions and that vary considerably across regions as well. On the other hand, Williamson (2002) and Bourguignon and Morrison (2002) stated that the diverging trend of world income has been mainly triggered by the rise of between-country inequality rather than by the rise of within-country inequality.

Neutel and Heshmati (2006) investigated the relationship between globalization, poverty and income inequality for 65 developing countries. Using the Kearney globalization index and cross-sectional regression analysis, the authors showed that there is a significant relationship between globalization and poverty and income inequality. In particular globalization leads to poverty reduction and it creates fairer income distribution.

The empirical evidence surveyed by Beck et al. (2007) demonstrated that greater financial development induces the incomes of the poor to grow faster than average per capita GDP growth, which leads lower income inequality. Similarly, investigating the relationship between financial development and income inequality, Clarke et al. (2006) found that financial development reduces income inequality.

Using the KOF Index and income and wage inequality data, Dreher and Gaston (2008) find evidence that overall globalization and the globalization have increased both industrial wage and household income inequality in OECD countries for the period of 1970 to 2000. Similarly, Bergh and Nilsson (2010) examined the correlation between the KOF index of globalization, the economic freedom index of the Fraser Institute and net income inequality for 79 countries for the period 1970-2005. Using a system GMM estimator, the authors concluded that reforms towards economic freedom tend to increase income inequality in rich countries and that social globalization is more important for middle and low income countries. Moreover, their empirical findings showed that monetary reforms, legal reforms and political globalization do not increase inequality.

Hameed and Nazir (2009) examined the relationship between economic globalization, poverty and inequality in Pakistan over the period of 1970 to 2004. Using data on poverty (head count ratio), income inequality (household Gini coefficient) and trade liberalization index (as a mode of globalization), the Granger causality test results indicated that greater trade liberalization is associated with higher income inequality and lower poverty.

Faustino and Vali (2011) analyzed the link between income inequality and economic globalization in OECD countries for the period 1995-2007. Using data on trade openness and foreign direct investment as proxy 
variables of economic globalization, the authors showed that trade openness decreases income inequality and that the foreign direct investment does not affect significantly income inequality. However, according to the static analysis conducted by means of the fixed effects estimator, trade openness leads to fairer income distribution, whereas foreign direct investments triggered more skewed income distributions.

Yanar and Şahbaz (2013) investigated the relationship between globalization, poverty and income inequality in 102 developing countries for the year 2010. Cross-sectional analysis revealed that economic, political and social globalization reduces poverty and income inequality among the countries, examined.

Asteriou et al. (2014) investigated the relationship between income inequality and globalization over the period 1995-2009 for the EU-27 countries and also for the Core, Periphery, High Technology, and New EU Member countries, with panel data techniques. The results suggested that trade openness, a mode of trade globalization, has decreased inequality both in the Core and the New EU member groups, while foreign investments, an other measurement of globalization, had a contribution in raising the Gini coefficient in the Core and the New EU member groups, but it had a contribution in reducing it in the Periphery.

\section{Technical issues}

\subsection{The Data and Model Specification}

In this study, we investigated the causality relationship between the KOF globalization indices (economic, political, social, and aggregate) and income inequality in the G7 countries (Canada, Germany, France, the United Kingdom, Italy Japan, and the United States) for the period 1970-2010.

The KOF globalization index, used intensely in recent years, covers more than 200 countries on a yearly basis from 1970 through 2012. The composite index and its subcomponents (economic, social and political) take values between 0 and 100, higher values representing more globalization.

Eviews 8.0 and Gauss 6.0 statistical packages were used in the econometric analyses. The variables, their explanations and sources are presented in Table 1 below.

Table 1. Data set

\begin{tabular}{|c|c|c|}
\hline Variables & Explanations & Source \\
\hline gini & ini coefficient & the WIID database (2014) \\
\hline eco_glob & $\begin{array}{l}\text { includes data on trade as a share of gross domestic product (GDP); foreign direct investment } \\
\text { stocks (\%of GDP); portfolio investment (\%of GDP); the indexes of hidden import barriers, of } \\
\text { mean tariff rate and of capital account restrictions from Gwartney et al. (2013)'s study and taxes }\end{array}$ & \\
\hline soc_glob & $\begin{array}{l}\text { on International Trade from various sources. } \\
\text { includes data on various personal contacts; the numbers of internet users and television; trade } \\
\text { in Newspapers; and cultural proximity from various sources. }\end{array}$ & $\begin{array}{l}\text { KOF Swiss Economic } \\
\text { Institute, ETH Zurich }\end{array}$ \\
\hline pol_glob & $\begin{array}{l}\text { includes data on membership in International Organizations, Participation in U.N. Security } \\
\text { Council Missions, Embassies in Country and International Treaties from various sources. }\end{array}$ & \\
\hline overall_glob & $\begin{array}{l}\text { includes in the above the three globalization indices, referring to data on actual economic flows, } \\
\text { on economic restrictions, on information flows, on personal contact, on cultural proximity. }\end{array}$ & \\
\hline
\end{tabular}

In order to investigate the presence of the causal relationships between the three dimensions of globalization and income inequality, the models for both the separate form and the aggregate form, described are as follows ( $\mathrm{t}$ is time period, $l$ is the lag length):

$$
\begin{aligned}
& \operatorname{gini}_{N t}=f\left(\text { gini }_{N t-l}, e c O_{-} g l o b_{N t-l}\right) \\
& \operatorname{gini}_{N t}=f\left(\operatorname{gini}_{N t-l}, s o c_{-} g l o b_{N t-l}\right) \\
& \operatorname{gini}_{N t}=f\left(\text { gini }_{N t-l}, p o l_{-} g l o b_{N t-l}\right) \\
& \operatorname{gini}_{N t}=f\left(\text { gini }_{N t-l}, \text { overall_}_{-} \text {glob }_{N t-l}\right)
\end{aligned}
$$

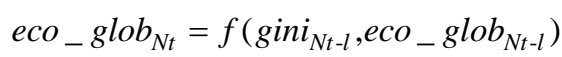

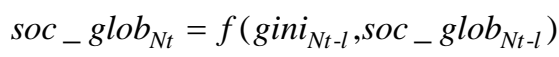

$$
\begin{aligned}
& p o l_{-} g l o b_{N t}=f\left(\text { gini }_{N t-l}, p_{0} g_{-} \operatorname{llob}_{N t-l}\right) \\
& \text { overall_}_{-} \text {glob }_{N t}=f\left(\text { gini }_{N t-l}, \text { overall }_{-} g l o b_{N t-l}\right)
\end{aligned}
$$

Table 2 presents descriptive statistics of data used in this paper. 
Table 2. Descriptive statistics

\begin{tabular}{lcccccc}
\hline & Mean & Median & Maximum & Minimum & Std. Dev. & Observation \\
\hline gini & 33.95 & 32.90 & 52.30 & 19.80 & 5.92 & 287 \\
eco_glob & 58.13 & 58.96 & 84.27 & 26.29 & 13.40 & 287 \\
soc_glob & 66.44 & 70.67 & 90.41 & 24.05 & 17.29 & 287 \\
pol_glob & 86.82 & 91.32 & 98.43 & 48.39 & 12.89 & 287 \\
overall_glob & 68.72 & 71.26 & 89.11 & 33.90 & 13.06 & 287 \\
\hline
\end{tabular}

Source: Authors' estimations.

Table 3 shows the correlation matrix of the variables. Apparently, KOF indices of globalization are positively correlated with Gini coefficient, used as a measurement of income inequality in both the separate form (eco_glob, soc_glob, pol_glob) and the aggregate form (overall_glob). These correlation coefficients seem to be less than 0.15 from Table 3 in below.

Table 3. Correlation matrix

\begin{tabular}{lcccc}
\hline & gini & eco_glob & soc_glob & pol_glob \\
\hline gini & 1 & 0.022 & 0.011 & 0.146 \\
eco_glob & 0.022 & 1 & 0.909 & 0.573 \\
soc_glob & 0.011 & 0.909 & 1 & 0.051 \\
pol_glob & 0.146 & 0.573 & 0.387 & 0.973 \\
overall_glob & 0.051 & 0.973 & 0.937 & 0.937 \\
\hline
\end{tabular}

Source: Authors' estimations.

\subsection{The Methodology and Findings}

We tested the presence of the causality relationship between income inequality and globalization in the G7 countries. For this purpose, we applied panel data techniques, which give more informative data, more variability, less co-linearity among the variables, more degrees of freedom and so, more efficiency (Baltagi, 2005).

\subsubsection{Cross-Sectional Dependence and Slope Homogeneity Tests}

Testing for cross-sectional dependence and the homogeneity of slope coefficients in a panel causality study is important for selecting the appropriate estimator. Especially, due to globalization and increasing integration of economies, cross-sectional dependence seems to be likely that shocks to individual countries affect other countries in the panel too. Hence, it might be necessary to control.

In this study, LMBP, Lagrange multiplier test statistic, developed by Breusch and Pagan (1980) and CDLM, CD tests, developed by Pesaran (2004) are used in order to control the presence of cross-sectional dependence among G7 countries.

The tests can be performed on the following panel data model:

$$
y_{i t}=\alpha_{i}+\beta_{i}^{\prime} x_{i t}+\mu_{i t} \text { for } \mathrm{i}=1,2, \ldots \mathrm{N} ; \quad \mathrm{t}=1,2, \ldots, \mathrm{T}
$$

where $\alpha_{i}$ is unit-specific intercept and bounded on a compact set, $x_{i t}$ is a kx1 vector of strictly exogenous regressors, $\beta_{i}$ is a kx1 vector of slope coefficients. In the cross-sectional dependence tests considered, the null and the alternative hypotheses of no cross-sectional dependence are as follows:

$H_{0}: \operatorname{Cov}\left(\mu_{i t}, \mu_{j t}\right)=0$ for all $\mathrm{t}$ and $i \neq j$

$H_{0}: \operatorname{Cov}\left(\mu_{i t}, \mu_{j t}\right) \neq 0$ for at least some $i \neq j$

The test statistics, developed by Breusch and Pagan (1980) and Pesaran (2004) are as follows:

$$
\begin{gathered}
L M_{B P}=T \cdot \sum_{i=1}^{N-1} \sum_{j=i+1}^{N} \hat{\rho}_{i j}^{2} \square \chi_{N .(N-1) / 2}^{2} \\
C D_{L M}=\sqrt{\frac{1}{N .(N-1)}\left[\sum_{i=1}^{N-1} \sum_{j=i+1}^{N}\left(T . \hat{\rho}_{i j}^{2}-1\right)\right] \square N(0,1)}
\end{gathered}
$$




$$
C D=\sqrt{\frac{2 T}{N .(N-1)}}\left[\sum_{i=1}^{N-1} \sum_{j=i+1}^{N} \hat{\rho}_{i j}\right] \square N(0,1)
$$

where $\hat{\rho}_{i j}$ shows the point estimation of the correlation coefficient among the residuals obtained from individual OLS estimations of Equation (1). Under the null hypothesis of no cross-sectional dependency, the $\mathrm{LM}_{\mathrm{BP}}$ test is used when $\mathrm{N}$ is fixed and $\mathrm{T}$ goes to infinity ( $\mathrm{T}$ is large relative to $\mathrm{N}$ ) and it is asymptotically distributed as chi-squared with N.(N-1)/2 degrees of freedom.

Under the null hypothesis of no cross-sectional dependence, $\mathrm{CD}_{\mathrm{LM}}$ test is used when $\mathrm{N}$ is great and $\mathrm{T}$ is small ( $\mathrm{N}$ is large relative to $\mathrm{T}$ ) and it is asymptotically distributed as standard normal.

An other test of Pesaran (2004) test is CD test. It is used when T and N go to infinity in any order and it is asymptotically distributed as standard normal.

When analyzing panel data, the other crucial issue to consider is the testing of slope homogeneity. In the study, it is investigated with Pesaran and Yamagata's (2008) homogeneity tests. Pesaran and Yamagata (2008) proposed a standardized version of Swamy's test of slope homogeneity for panel data models. Pesaran and Yamagata (2008) take into account the equation (1). The null hypothesis and the alternative hypothesis of interest are

$H_{0}: \beta_{i}=\beta$ for all $\mathrm{i}$,

$H_{1}: \beta_{i} \neq \beta_{j}$ for a non-zero fraction of pairwise slopes for $i \neq j$.

Under the null hypothesis $\tilde{\Delta} \rightarrow{ }_{d} N(0,1)$ as $(N, T) \stackrel{{ }^{j}}{\rightarrow} \infty$ so long as $\sqrt{N} / T^{2} \rightarrow 0$,

where the standardized dispersion statistic, $\tilde{\Delta}$ is defined by $\tilde{\Delta}=\sqrt{N} \cdot\left(\frac{N^{-1} \tilde{S}-k}{\sqrt{2 k}}\right)$ where $\tilde{S}$ is the Swamy's statistic and it is valid for a fixed $\mathrm{N}$ and as $T \rightarrow \infty$. Pesaran and Yamagata (2008) also proposed the adjusted version of $\tilde{\Delta}$ for the small samples (Note 1 ).

$\tilde{\Delta}_{a d j}=\sqrt{N} \cdot\left(\frac{N^{-1} \tilde{S}-E\left(\tilde{z}_{i T}\right)}{\sqrt{\operatorname{Var}\left(\tilde{z}_{i T}\right)}}\right)$, where $E\left(\tilde{z}_{i T}\right)=k, \operatorname{Var}\left(\tilde{z}_{i T}\right)=\frac{2 k \cdot(T-k-1)}{T+1}$.

The empirical findings of cross-sectional dependence and slope homogeneity tests are presented in Table 4 and Table 5, respectively. It is clear that the null of no cross-sectional dependence across the G7 countries is strongly rejected from Table 4.

From Table 5, the results of the delta test statistics indicate that the homogeneity tests reject the equality hypothesis for both separately globalization indices (eco_glob, soc_glob, pol_glob) and aggregate globalization index (overall_glob), supporting that the slope coefficients are heterogeneous. So, it should be applied the causality test, taking into account both cross-sectional dependence and slope heterogeneity.

Table 4. Results for cross-sectional dependence

\begin{tabular}{|c|c|c|c|c|c|}
\hline & gini & eco_glob & soc_glob & pol_glob & overall_glob \\
\hline $\mathrm{LM}_{\mathrm{BP}}$ & $54.809 * * *$ & $57.873^{* * * *}$ & $46.616^{* *}$ & $113.049 * * *$ & $37.900 * *$ \\
\hline $\mathrm{CD}_{\mathrm{LM}}$ & $5.217 * * *$ & $5.690 * * *$ & $3.953 * * *$ & $14.203 * * *$ & $2.608 * * *$ \\
\hline $\mathrm{CD}$ & $-4.276 * * *$ & $-4.347 * * *$ & $-4.447 * * *$ & $1.408^{*}$ & $-4.342 * * *$ \\
\hline
\end{tabular}

$* * *, * *, *$ indicate rejection of the null hypothesis at the 1,5 , and 10 percent levels of significance, respectively.

Source: Authors' estimations. 
Table 5. Results for the slope homogeneity tests

\begin{tabular}{|c|c|c|c|c|}
\hline Models & $\tilde{\Delta}$ test statistic & prob. value & $\tilde{\Delta}_{a d j}$ test statistic & prob. value \\
\hline$g i n i_{N t}=f\left(g i n i_{N t-l}, e c o-g l o b_{N t-l}\right)$ & $4.493 * * *$ & 0.000 & $4.662 * * *$ & 0.000 \\
\hline$g i n i_{N t}=f\left(g i n i_{N t-l}, s O c_{-} g l o b_{N t-l}\right)$ & $6.149 * * *$ & 0.000 & $6.382 * * *$ & 0.000 \\
\hline$g i n i_{N t}=f\left(g i n i_{N t-l}, p o l_{-} g l o b_{N t-l}\right)$ & $2.218^{* *}$ & 0.013 & $2.301 * * *$ & 0.000 \\
\hline$g i n i_{N t}=f\left(g_{i n i_{N t-l}}, o_{\text {verall }}\right.$ glob $\left._{N t-l}\right)$ & $5.652^{* * *}$ & 0.011 & $6.865^{* * * *}$ & 0.000 \\
\hline$e c O_{-} g l o b_{N t}=f\left(g_{i n i_{N t-l}}, e c o_{-} g l o b_{N t-l}\right)$ & $5.183 * * *$ & 0.000 & $5.373 * * *$ & 0.000 \\
\hline$s O c_{-} g l o b_{N t}=f\left(g_{i n i_{N t-l}}, s O c_{-} g l o b_{N t-l}\right)$ & $6.512 * * *$ & 0.000 & $6.752^{* * * *}$ & 0.000 \\
\hline$p o l_{-} g l o b_{N t}=f\left(g i n i_{N t-l}, p o l_{-} g l o b_{N t-l}\right)$ & $2.410^{* * * *}$ & 0.008 & $2.499 * * *$ & 0.006 \\
\hline overall $_{-}$glob $_{N t}=f\left(\operatorname{gini}_{N t-l}\right.$, overall $\left._{-} g l o b_{N t-l}\right)$ & $5.830^{* * *}$ & 0.000 & $6.045^{* * *}$ & 0.000 \\
\hline
\end{tabular}

$* * *, * *, *$ indicate rejection of the null hypothesis at the 1,5 , and 10 percent levels of significance, respectively.

Source: Authors' estimations.

\subsubsection{Panel Causality Test}

Due to the findings of cross-sectional dependence and country-specific heterogeneity, in this study the bootstrap panel causality approach, developed by Kónya (2006) is applied to investigate the direction of causality between income inequality and globalization. This panel causality approach is based on Seemingly Unrelated Regressions (SUR) and Wald tests with country specific bootstrap critical values. This approach does not require pre-testing for unit root and cointegration since country specific bootstrap critical values are generated (Kónya, 2006).

To test for the causal relationship between two variables researchers have used Granger causality test. Granger (1969) called a variable $\mathrm{x}$ causal for a variable $\mathrm{y}$, if the information provided by past and present values of $\mathrm{x}$ significantly helps to forecast $y$ for some future period. In testing the Granger causality among the variables in a panel data if there is a cross-sectional dependence, estimating sets of equations by the Seemingly Unrelated Regressions (SUR) procedure gives more efficient estimators than OLS estimation method (Zellner, 1962).

The panel causality approach of Kónya (2006), which allows for both cross-sectional dependence and country-specific heterogeneity, which is based on SUR systems:

$$
\begin{aligned}
& y_{1, t}=\alpha_{1,1}+\sum_{k=1}^{l y 1} \beta_{1,1, k} y_{1, t-k}+\sum_{k=1}^{l x 1} \delta_{1,1, k} x_{1, t-k}+e_{1,1, t} \\
& y_{2, t}=\alpha_{1,2}+\sum_{k=1}^{l y 1} \beta_{1,2, k} y_{2, t-k}+\sum_{k=1}^{l x 1} \delta_{1,2, k} x_{2, t-k}+e_{1,2, t} \\
& \vdots \\
& y_{N, t}=\alpha_{1, N}+\sum_{k=1}^{l y 1} \beta_{1, N, k} y_{N, t-k}+\sum_{k=1}^{l x 1} \delta_{1, N, k} x_{N, t-k}+e_{1, N, t} \\
& \quad \text { and } \\
& x_{1, t}=\alpha_{2,1}+\sum_{k=1}^{l y 2} \beta_{2,1, k} y_{1, t-k}+\sum_{k=1}^{l x 2} \delta_{2,1, k} x_{1, t-k}+e_{2,1, t} \\
& x_{2, t}=\alpha_{2,2}+\sum_{k=1}^{l y 2} \beta_{2,2, k} y_{2, t-k}+\sum_{k=1}^{l x 2} \delta_{2,2, k} x_{2, t-k}+e_{2,2, t} \\
& \vdots \\
& x_{N, t}=\alpha_{2, N}+\sum_{k=1}^{l y 2} \beta_{2, N, k} y_{N, t-k}+\sum_{k=1}^{l x 2} \delta_{2, N, k} x_{N, t-k}+e_{2, N, t}
\end{aligned}
$$

where y denotes income inequality (i.e., gini), x refers to the globalization indices (i.e., eco_glob, soc_glob, pol_glob and overall_glob), index $\mathrm{t}$ refers to the time period $t=1,2, \ldots, T, \mathrm{k}$ the lag, $l y 1, l y 2, l x 1, l x 2$ indicate the longest lags in the system, and $\mathrm{N}$ is the number of the members in a panel $j=1,2, \ldots, N$. The error terms 
$e_{1,1, t}, e_{1,2, t}, \ldots, e_{1, N, t}$ and $e_{2,1, t}, e_{2,2, t}, \ldots, e_{2, N, t}$ are supposed to be white-noises and may be contemporaneously correlated.

With respect to this system, in country $\mathrm{N}$ there is one-way Granger causality running from $\mathrm{x}$ to $\mathrm{y}$ if not all $\delta_{1, j, k}$ 's

are zero, but all $\beta_{2, j, k}$ 's are zero; there is one-way Granger causality from y to $\mathrm{x}$ if all $\delta_{1, j, k}$ 's are zero, but not all

$\beta_{2, j, k}$ 's are zero; there is two-way Granger causality between $\mathrm{y}$ and $\mathrm{x}$ if neither all $\delta_{1, j, k}$ 's nor all $\beta_{2, j, k}$ 's are zero

and there is no Granger causality between $\mathrm{y}$ and $\mathrm{x}$ if all $\delta_{1, j, k}$ 's and $\beta_{2, j, k}$ 's are zero.

This system is estimated by the SUR estimator. So, it is taken into account contemporaneous correlation within the system. Kónya (2006)'s approach tests for Granger causality from $\mathrm{x}$ to $\mathrm{y}$ and from $\mathrm{y}$ to $\mathrm{x}$ in performing Wald tests with country specific bootstrap critical values. Following Konya (2006), we use country specific bootstrap Wald critical values to implement Granger causality. Generating bootstrap Wald critical allows y and x not be necessary stationary.

Since the results from the panel causality may be sensitive to the lag structure, we determine the optimal lag structure in the equations by using 1 to 4 lags and then choosing the combinations, minimizing the Schwarz Bayesian Criterion.

The results of the causality test from economic globalization to income inequality and from income inequality to economic globalization are shown in Table 6. Also, estimated coefficients of interest in the causality test are shown in Table 10. From Table 6 and Table 10, it is possible to observe that economic globalization positively causes income inequality for Canada and the United Kingdom and negatively for France. On the other hand, causality from income inequality to economic globalization is detected for only the United Kingdom. Thus, the results of causality test show a significant two-way causality relationship between economic globalization and income inequality for the United Kingdom.

Table 6. Results for panel causality

\begin{tabular}{lcccccccc}
\hline & Ho: eco_glob does not cause gini & \multicolumn{4}{c}{ Ho: gini does not cause eco_glob } \\
\hline \multicolumn{1}{c}{ Countries } & Wald Stat. & \multicolumn{3}{c}{ Bootstrap Critical Values } & Wald Stat. & \multicolumn{2}{c}{ Bootstrap Critical Values } \\
\hline \multirow{3}{*}{ Canada } & & $1 \%$ & $5 \%$ & $10 \%$ & & $1 \%$ & $5 \%$ & $10 \%$ \\
Germany & $6.59^{* *}$ & 10.08 & 5.66 & 3.88 & 0.51 & 10.66 & 5.96 & 4.16 \\
France & 0.26 & 8.98 & 5.22 & 3.61 & 0.96 & 10.50 & 5.94 & 4.04 \\
the United Kingdom & $11.09 * * *$ & 9.11 & 5.29 & 3.75 & 2.93 & 21.36 & 6.63 & 3.70 \\
Italy & $6.87 * *$ & 10.57 & 5.71 & 3.98 & $4.25 *$ & 10.92 & 5.92 & 4.00 \\
Japan & 3.07 & 9.15 & 5.19 & 3.51 & 0.12 & 11.81 & 5.83 & 3.91 \\
The United States & 0.49 & 8.63 & 4.99 & 3.54 & 0.97 & 11.86 & 6.22 & 4.07 \\
\hline
\end{tabular}

***,**** indicate significance at the $1 \%, 5 \%$ and $10 \%$ levels, respectively.

Source: Authors' estimations.

The results of the causality test from social globalization to income inequality and from income inequality to social globalization are showed in Table 7. The results in Table 7 and Table 10 show that there is a significant negative causality running from social globalization to income inequality for France and there is a significant positive causality running from social globalization to income inequality for the United Kingdom. For the other countries there is no significant causal relationship running from social globalization to income inequality. On the other hand, Table 7 shows that, in any country, there is no causality from income inequality to social globalization. 
Table 7. Results for panel causality

\begin{tabular}{lcccccccc}
\hline & \multicolumn{3}{c}{$\mathrm{H}_{\mathrm{o}}$ : soc_glob does not cause gini } & \multicolumn{3}{c}{$\mathrm{H}_{0}$ : gini does not cause soc_glob } \\
\hline \multicolumn{1}{c}{ Countries } & Wald Stat. & \multicolumn{3}{c}{ Bootstrap Critical Values } & Wald Stat. & \multicolumn{3}{c}{ Bootstrap Critical Values } \\
& & $1 \%$ & $5 \%$ & $10 \%$ & & $1 \%$ & $5 \%$ & $10 \%$ \\
Canada & 3.18 & 10.23 & 5.61 & 3.90 & 0.28 & 8.89 & 5.34 & 3.90 \\
Germany & 0.21 & 10.05 & 5.62 & 3.90 & 3.43 & 12.97 & 6.33 & 4.11 \\
France & $13.79^{* * *}$ & 9.35 & 5.42 & 3.81 & 2.52 & 21.40 & 5.05 & 3.20 \\
The United Kingdom & $8.28^{* * *}$ & 10.20 & 5.77 & 3.96 & 0.50 & 13.10 & 6.98 & 4.27 \\
Italy & 1.76 & 8.90 & 5.26 & 3.77 & 0.49 & 19.63 & 6.37 & 3.80 \\
Japan & 1.83 & 10.13 & 5.44 & 3.72 & 0.14 & 17.37 & 7.10 & 4.02 \\
The United States & 3.20 & 8.91 & 4.94 & 3.42 & 3.28 & 9.43 & 5.60 & 4.08 \\
\hline
\end{tabular}

$* * *, * * *$ indicate significance at the $1 \%, 5 \%$ and $10 \%$ levels, respectively.

Source: Authors' estimations.

The results of the causality tests from political globalization to income inequality and from income inequality to political globalization are shown in Table 8 . The results of causality test in Table 8 show that, in any country, there is no causality from income inequality to political globalization. However, the results in Table 8 and Table 10 show that, for only France, there is a significant negative causality running from political globalization to income inequality, whereas for the other countries there is no significant causality running from social globalization to income inequality.

Table 8. Results for panel causality

\begin{tabular}{lcccccccc}
\hline & \multicolumn{3}{c}{ Ho: pol_glob does not cause gini } & \multicolumn{3}{c}{ Ho: gini does not cause pol_glob } \\
\hline Countries & Wald Stat. & \multicolumn{3}{c}{ Bootstrap Critical Values } & Wald Stat. & \multicolumn{3}{c}{ Bootstrap Critical Values } \\
\hline & & $1 \%$ & $5 \%$ & $10 \%$ & & $1 \%$ & $5 \%$ & $10 \%$ \\
Canada & 0.80 & 10.50 & 5.73 & 3.88 & 0.27 & 10.10 & 5.61 & 3.81 \\
Germany & 1.13 & 9.93 & 5.58 & 3.94 & 0.55 & 12.05 & 6.11 & 3.93 \\
France & $4.67 *$ & 10.32 & 5.91 & 4.18 & 1.56 & 24.33 & 6.41 & 3.87 \\
The United Kingdom & 1.34 & 13.91 & 6.91 & 4.65 & 0.33 & 10.29 & 5.60 & 3.96 \\
Italy & 1.29 & 9.44 & 5.49 & 3.88 & 0.61 & 12.65 & 6.04 & 3.98 \\
Japan & 0.35 & 8.57 & 5.31 & 3.77 & 0.02 & 14.03 & 5.98 & 3.71 \\
The United States & 1.62 & 8.95 & 5.15 & 3.55 & 0.37 & 10.25 & 5.75 & 4.03 \\
\hline
\end{tabular}

***, **** indicate significance at the $1 \%, 5 \%$ and $10 \%$ levels, respectively.

Source: Authors' estimations.

The results of the causality test from overall globalization to income inequality and from income inequality to overall globalization are presented in Table 9. When analyzing the causality relationship between overall globalization and income inequality, instead of the globalization indices in the separate form, the results in Table 9 and Table 10 show that overall globalization positively causes income inequality for Canada and the United Kingdom and negatively for France. On the other hand, according to the results in Table 9, in any country, there is no causality from income inequality to overall globalization.

Table 9. Results for panel causality

\begin{tabular}{|c|c|c|c|c|c|c|c|c|}
\hline \multirow{3}{*}{ Countries } & \multicolumn{4}{|c|}{ Ho: overall_glob does not cause gini } & \multicolumn{4}{|c|}{ Ho: gini does not cause overall_glob } \\
\hline & \multirow[t]{2}{*}{ Wald Stat. } & \multicolumn{3}{|c|}{ Bootstrap Critical Values } & \multirow[t]{2}{*}{ Wald Stat. } & \multicolumn{3}{|c|}{ Bootstrap Critical Values } \\
\hline & & $1 \%$ & $5 \%$ & $10 \%$ & & $1 \%$ & $5 \%$ & $10 \%$ \\
\hline Canada & $4.53^{*}$ & 10.15 & 5.65 & 3.84 & 0.87 & 10.44 & 5.74 & 3.96 \\
\hline Germany & 0.20 & 8.69 & 5.02 & 3.50 & 6.88 & 12.91 & 6.18 & 4.05 \\
\hline France & $12.38 * * *$ & 9.30 & 5.15 & 3.52 & 3.60 & 17.46 & 5.88 & 3.62 \\
\hline The United Kingdom & $7.94 * *$ & 9.54 & 5.36 & 3.83 & 0.11 & 12.01 & 6.17 & 4.11 \\
\hline Italy & 2.24 & 9.16 & 5.26 & 3.68 & 0.42 & 15.72 & 6.05 & 3.89 \\
\hline Japan & 1.16 & 8.54 & 5.08 & 3.58 & 0.12 & 13.01 & 6.49 & 4.12 \\
\hline The United States & 3.11 & 8.14 & 4.70 & 3.29 & 0.34 & 9.95 & 5.73 & 4.08 \\
\hline
\end{tabular}

$* * *, * * *$ indicate significance at the $1 \%, 5 \%$ and $10 \%$ levels, respectively.

Source: Authors' estimations. 
Table 10. Results for the signs of the causality relationships of interest

\begin{tabular}{|c|c|c|c|}
\hline Hypotheses & Countries & Estimated coefficient & p-val. \\
\hline \multirow{7}{*}{$\mathrm{H}_{\mathrm{o}}$ : eco_glob does not cause gini } & Canada & $0.33 * *$ & 0.010 \\
\hline & Germany & 0.05 & 0.608 \\
\hline & France & $-0.20 * * *$ & 0.001 \\
\hline & The United Kingdom & $0.30 * * *$ & 0.009 \\
\hline & Italy & $-0.07 * * *$ & 0.008 \\
\hline & Japan & 0.04 & 0.480 \\
\hline & The United States & 0.15 & 0.161 \\
\hline \multirow{7}{*}{$\mathrm{H}_{\mathrm{o}}$ : soc_glob does not cause gini } & Canada & $0.20^{*}$ & 0.075 \\
\hline & Germany & 0.04 & 0.645 \\
\hline & France & $-0.16^{* * *}$ & 0.004 \\
\hline & The United Kingdom & $0.23 * * *$ & 0.000 \\
\hline & Italy & -0.04 & 0.184 \\
\hline & Japan & 0.06 & 0.176 \\
\hline & The United States & $0.11^{*}$ & 0.073 \\
\hline \multirow{7}{*}{$\mathrm{H}_{\mathrm{o}}$ : pol_glob does not cause gini } & Canada & 0.21 & 0.361 \\
\hline & Germany & 0.05 & 0.280 \\
\hline & France & $-0.61^{* *}$ & 0.030 \\
\hline & The United Kingdom & -0.64 & 0.241 \\
\hline & Italy & -0.22 & 0.250 \\
\hline & Japan & 0.02 & 0.550 \\
\hline & The United States & 0.22 & 0.201 \\
\hline \multirow{7}{*}{$\begin{array}{l}\mathrm{H}_{\mathrm{o}} \text { : overall_glob does not cause } \\
\text { gini }\end{array}$} & Canada & $0.31 * *$ & 0.033 \\
\hline & Germany & 0.03 & 0.652 \\
\hline & France & $-0.23 * * *$ & 0.000 \\
\hline & The United Kingdom & $0.37 * * *$ & 0.005 \\
\hline & Italy & -0.07 & 0.135 \\
\hline & Japan & 0.06 & 0.282 \\
\hline & The United States & $0.17 *$ & 0.078 \\
\hline
\end{tabular}

$* * *, * * * *$ denote significance at the $1 \%, 5 \%$ and $10 \%$ levels, respectively.

Source: Authors' estimations.

\section{Conclusion}

Defenders of economic globalization view it as a key to future economic development and in general it is considered a positive power for improved quality of life, acceleration of economic growth, efficient allocation of resources and greater productivity enhancements. Whereas, anti-globalization thinkers argue that it increases poverty and leads to worsening in the distribution of income. From this point of view, this paper attempted to answer the following question: "Are increases in globalization associated with increasing income inequality among G7 countries over the period 1970-2010?" To this end, it was used Kónya (2006)'s bootstrap panel Granger causality method, which takes into account simultaneously cross-sectional dependence and country-specific heterogeneity.

Empirical results show that economic globalization positively causes income inequality for Canada and the United Kingdom and negatively for France. On the other hand, causality running from income inequality to economic globalization is detected for only the United Kingdom. Thus, the results of causality test showed that there is a significant two-way causality relationship between economic globalization and income inequality for the United Kingdom.

Our results also show that there is a significant negative causal relationship running from social globalization to income inequality for France and there is significant positive causality running from social globalization to income inequality for United Kingdom. For the other countries there is no significant causal relationship running from social globalization to income inequality.

Moreover, the results suggest that, in any country, there is no causality from income inequality to political globalization, while for only France, a significant negative causal relationship is detected running from political globalization to income inequality. 
When analyzing the causal relationship between overall globalization and income inequality, it is observed that overall globalization positively causes income inequality for Canada and the United Kingdom and negatively for France. On the other hand, it is observed that in any country, there is no causality from income inequality to overall globalization.

In short, globalization has mixed effects on the income distribution of G7 countries. It significantly increases poverty and worsens the income distribution in the cases of Canada and the United Kingdom. On the other hand, positive impacts of globalization have been witnessed in France.

Lastly, if countries want to reap maximum benefit from economic globalization, it needs to be accompanied with adoption of pro-poor growth policies which emphasize investment in human development and provide a structure for social safety nets for the poor. So, the magnitude of benefits reaped from the globalization in any economy may be largely affected from domestic macroeconomic policies, market structure, initial condition of economy, quality of institution and degree of political stability.

Consequently, education and anti-discrimination policies, well-designed labor market institutions and progressive tax and transfer systems can reduce income inequality and increase productivity.

\section{References}

Agénor, P. R. (2004). Does globalization hurt the poor? International Economics and Economic Policy, IEEP 2004(1), 1-31.

Asteriou, D., Sophia, D., \& Argiro, M. (2014). Globalization and income inequality: A panel data econometric approach for the EU27 countries. Economic Modelling, 36(2014), 592-599. http://dx.doi.org/10.1016/j.econmod.2013.09.051

Baltagi B. (2005). Econometric Analysis of Panel Data (3rd ed.). Chichester: John Wiley Sons, Ltd.

Beck, T., Demirgüc-Kunt, A., \& Levine, R. (2007). Finance, inequality, and the poor. J. Econ. Growth, 12, 27-49. http://dx.doi.org/10.1007/s10887-007-9010-6

Bergh, A., \& Nilsson, T. (2010). Do liberalisation and globalisation increase income inequality? European Journal of Political Economy. http://dx.doi.org/10,1016/j.ejpoleco.2010.03.002

Bourguignon, F., \& Morrison, C. (2002). Inequality among World Citizens, 1820-1992. American Economic Review, 92(4), 727-744. http://dx.doi.org/10.1257/00028280260344443

Breusch, T., \& Pagan, A. (1980). The LM test and its applications to model specification in econometrics. Review of Economic Studies, 47, 239-254. http://dx.doi.org/10.2307/2297111

Clarke, G. L., Xu, C., \& Zou, H. (2006). Finance and Income Inequality: What Do the Data Tell Us? Southern Economic Journal, 72, 578-596. http://dx.doi.org/10.2307/20111834

Dollar, D., \& Kraay, A. (2002). Growth is good for the poor. Journal of Economic Growth, 7, 195-225. http://dx.doi.org/10.1023/A:1020139631000

Dollar, D., \& Kraay, A. (2004). Trade, Growth and Poverty. The Economic Journal, 114, F22-F49. http://dx.doi.org/10.1111/j.0013-0133.2004.00186.x

Dreher, A., \& Gaston, N. (2008). Has globalization increased inequality? Review of International Economics, 16, 516-536. http://dx.doi.org/10.1111/j.1467-9396.2008.00743.x

Dreher, A. (2006). Does Globalization Affect Growth? Empirical Evidence from a new Index. Applied Economics, 38(10), 1091-1110. http://dx.doi.org/10.1111/j.1467-9396.2008.00743.x

Faustino, H., \& Vali, C. (2011). The Effects of Globalisation on OECD Income Inequality: A static and dynamic analysis. School of Economics and Management, Technical University of Lisbon WP 12/2011/DE.

Granger. C. W. J. (1969). Investigating causal relations by econometric models and cross-spectral methods. Econometrica, 37, 424-438. http://dx.doi.org/10.2307/1912791

Hameed, A., \& Anila, N. (2009). Economic Globalisation and Its Impact on Poverty and Inequality: Evidence from Pakistan. ECO Economic Journal, 1.

Heshmati, A. (2004). The Relationship between Income Inequality, Poverty and Globalization. IZA Discussion Paper 2004.

ILO. (2004). A Fair Globalization: Creating Opportunities for All the World Commission on the Social Dimension of Globalization. ILO Publications. 
Jalil, A. (2012). Modeling income inequality and openness in the framework of Kuznets curve: New evidence from China. Econ. Model., 29, 309-315. http://dx.doi.org/10.1016/j.econmod.2011.10.012

K'onya, L. (2006). Exports and growth: Granger causality analysis on OECD Countries with a panel data approach. Economic Modelling, 23, 978-992. http://dx.doi.org/10.1016/j.econmod.2006.04.008

Kalwij, A., \& Verschoor, A. (2005). A Decomposition of Poverty Trends across Regions: The Role of Variation in the Income and Inequality Elasticities of Poverty. WIDER RP no. 2005/36.

KOF. (2014). Index of Globalization. Retrieved from http://globalization.kof.ethz.ch/

Maskin, E. (2014). Theorist Eric Maskin: Globalization Is Increasing Inequality. Retrieved from http://www.worldbank.org/en/news/feature/2014/06/23/theorist-eric-maskin-globalization-is-increasing-ine quality

Milanovic, B. (2002). Can We Discern the Effect of Globalization on Income Distribution? Evidence from Household Budget Surveys. WB Policy Research Working Paper 2876. Washington, DC: World Bank. http://dx.doi.org/10.1596/1813-9450-2876

Neutel, M., \& Heshmati, A. (2006). Globalisation, Inequality and Poverty Relationships: A Cross Country Evidence. IZA Discussion Paper No. 2223.

OECD. (2012). Economic Policy Reforms 2012 Going for Growth: Going for Growth. OECD Publishing.

Pesaran, M. H., \& Yamagata, T. (2008). Testing slope homogeneity in large panels. Journal of Econometrics, 142, 50-93. http://dx.doi.org/10.1016/j.jeconom.2007.05.010

Pesaran, M. H. (2004). General Diagnostic Tests for Cross Section Dependence in Panels. CESifo Working Paper 1229; IZA Discussion Paper 1240.

Swamy, P. A. V. B. (1970). Efficient inference in a random coefficient regression model. Econometrica, 38, 311-323. http://dx.doi.org/10.2307/1913012

UN Development Programme. (UNDP). Humanity Divided: Confronting Inequality in Developing Countries. November 2013.

UNU-WIDER World Income Inequality Database, Version 3.0B. (2014). United Nations University-World Institute for Development Economics Research. Retrieved from http://www.wider.unu.edu/research/WIID3-0B/en_GB/database/

Williamson, J. G. (2002). Winners and Losers over Two Centuries of Globalization. WIDER Annual Lecture 6. Helsinki: UNU-WIDER. http://dx.doi.org/10.3386/w9161

Yanar, R., \& Şahbaz, A. (2013). Gelişmekte Olan Ülkelerde Küreselleşmenin Yoksulluk ve Gelir Eşitsizliği Üzerindeki Etkileri. Eskişehir Osmangazi Üniversitesi İ̈BF Dergisi, 8(3), 55-74.

Zellner. A. (1962). An Efficient Method of Estimating Seemingly Unrelated Regressions and Tests for Aggregation Bias. Journal of the American Statistical Association, 57, 348-368. http://dx.doi.org/10.1080/01621459.1962.10480664

\section{Note}

Note 1. For a detailed proof and information, see Swamy (1970), and Pesaran and Yamagata (2008).

\section{Copyrights}

Copyright for this article is retained by the author(s), with first publication rights granted to the journal.

This is an open-access article distributed under the terms and conditions of the Creative Commons Attribution license (http://creativecommons.org/licenses/by/3.0/). 